\title{
Videoclubes, distribuidores, locadores e revendedores de videocassetes: sua posição frente ao Direito de Autor
}

\author{
Prof. Antônio Chaves \\ ex-diretor da Faculdade de Direito da USP
}

\begin{abstract}
RESUMO: 1. A difícil conciliação entre os interesses dos autores e artistas intérpretes e os da coletividade. Doutrina. 2. Leis e jurisprudência em diferentes países. 3. Congressos internacionais. 4. A situação em nosso país. 5 . O controle de videocassetes, a reserva de mercado e o registro de gravadores pelas resoluções concine $\mathrm{n}^{\circ} \mathrm{s} 97,98$ e 99 . 6. A única solução plausível: remuneração pela "potencialidade" de gravação de obras protegidas pelo direito autoral. Um projeto de lei brasileiro. 7. Quando e como será cobrado o novo direito. 8. Uma complementação necessária. 9. Um "compromisso" não pode estabelecer obrigações para exclusivamente uma das partes signatárias. 10. A distribuição e locação de videocassetes não são crimes contra a propriedade imaterial.
\end{abstract}

RIASSUNTO: 1 . La difficile conciliazione tra gli interessi degli autori e degli aristi interpreti e quelli della colletività. Dottrina. 2. Leggi e giurisprudenza in varie nazioni. 3. Congressi internazionali. 4. La situazione in Brasile. 5. Il controllo di video-cassette, la riserva del mercato e il registro di incisiori per le Risoluzioni Concine numeri 97, 98 e 99. 6. L'unica soluzione plausibile: rimunerazione per la "potenzialitá" di incisione di opere protette tal diritto di autore. Un proggetto di legge brasiliano. 7. Quando e come sará riscosso il nuovo diritto. 8. Una complementazione necessaria. 9. Un "compromesso" non puó stabilire obblighi esclusivamente a carico di una delle parti sottoscrittrici. 10. La distribuzione e locazione di vidiocassete non costituiscono delitto contro la proprietà immateriale.

\section{CONSULTA}

Procurando dar uma solução racional e equitativa ao problema da retribuição do direito de autor e conexos em matéria de videocassetes, várias negociações foram mantidas entre, de um lado, os produtores cinematográficos e detentores de direitos sobre obras cinematográficas sob a forma de videocassetes, e, de outro, videoclubes, distribuidores, locadores e revendedores dessas obras, individualmente ou através das Associações que os representam, no sentido de se coibir a copiagem e comercialização de filmes cinematográficos e sua locação não autorizadas, que tiveram remate com a assinatura, no Rio de Janeiro, em data de 07.06.1984, de um "Protocolo de Intenções". 
Tendo porém surgido dúvidas sobre o alcance, a finalidade e o próprio cumprimento do convencionado, distingue-me o sr. ADELINO DOS SANTOS ABREU, Presidente da ABEVC-Associação Brasileira de Empresas de Videocomunicação e da OMNI Vídeo, com pedido de parecer, consubstanciado em três quesitos, que passo a reproduzir, para acompanhá-los das considerações pertinentes e respectivas respostas.

\section{PARECER}

\section{A DIFÍCIL CONCILIAÇÃO ENTRE OS INTERESSES DOS AUTO- RES E ARTISTAS INTÉRPRETES E OS DA COLETIVIDADE. DOUTRINA}

QUESITO no 1 "Na ausência de dispositivos que incriminem a gravação para uso particular, que é eventualmente praticada pelos associados dos videoclubes, qual a situação das locadoras e distribuidoras? Que providências legais devem tomar para tornar efetiva a intenção, já reiteradamente demonstrada, de legalizarem sua posição perante os titulares de direitos autorais?"

Autoriza o art. 49, no II da Lei no 5.988, de 14.12.1973, "A reprodução, em um só exemplar, de qualquer obra, contanto que não se destine à utilização com intuito de lucro".

Com a proliferação dos aparelhos "xerox" ou similares, passaram a multiplicar-se aos milhões, por toda parte, as cópias de trabalhos literários ou musicais, em letra de forma, sem que, no mundo inteiro, com raras exceções, tenha a legislação conseguido resolver o problema a contento.

O mesmo fenômeno repete-se, agora, no que diz respeito às obras musicais, com os aparelhos gravadores de fitas, cassetes, filmes cinematográficos, videocassetes e similares, que permitem a gravação de espetáculos transmitidos pelo cinema, pela TV, por satélites, e espetáculos públicos, diretamente.

Sem embargo, a fixação de obras alheias numa fita magnética, sem autorização, objetivando fins de lucro direto ou indireto, implica numa reprodução não permitida, correspondendo a um verdadeiro locupletamento, como jamais deixou de reconhecer a Consulente, cuja maior preocupação é justamente a solução equitativa desse problema.

Tem-se salientado, com efeito, não haver razão para que apenas os autores, os artistas intérpretes e executantes e os empresários devam suportar o ônus 
dessa evolução, tanto mais quanto ninguém lembraria de discutir a necessidade de pagar os aparelhos e o material utilizados.

Raros são os que não tenham se valido, hoje em dia, dos préstimos dos aparelhos gravadores de sons e de imagens, prática que, aliada à televisão, constitui um dos motivos que levou à atual crise as grandes empresas produtoras de filmes cinematográficos, fenômenos que levanta, entre outras, quatro principais questões distintas, embora intimamente relacionadas: 1. a da retribuição dos autores, artistas, empresas gravadoras, cinematográficas, de rádios e de TV; 2. a mesma retribuição pelo aproveitamento, ou reaproveitamento, não autorizado, em transmissões ao público de suas produções ou transmissões; 3. a da pirataria: aproveitamento ilícito da obra intelectual alheia mediante a reprodução, multiplicação e lançamento no mercado sem autorização, de cassetes, videocassetes, cartuchos, discos, filmes cinematográficos e análogos, etc.; 4. 0 da locação, sem autorização dos titulares de direito, dessas produções.

Coloca REINHOLD KREILE, Vervielfätigung zum persönlichen Gebrauch (Reprodução destinada ao uso pessoal) Anuário 1979 da Internationale Gesellschaft für Urheberrecht, E.V., Viena, 1979, págs. 94-114, em oposição à prerrogativa exclusiva de reprodução, parte essencial do direito de autor individual, o axioma que reconhece ao público o livre acesso às obras literárias e artísticas.

Os progressos da técnica oneram o direito de reprodução exclusiva com conseqüências cada vez mais freqüentes e pesadas, situação nova que exige que a reprodução privada seja submetida a limitações, não podendo mais continuar a escapar às conseqüências econômicas.

Reconhece que na maior parte dos países parte-se do princípio de que a retribuição do autor para a reprodução com finalidades privadas deve ser paga por aquele mesmo que faz a reproduçāo.

Seja qual for a solução considera que o legislador deverá levar em conta dois princípios:

1. o direito de autor não pode opor-se à evolução técnica e econômica;

2. o autor deve ser indenizado pecuniariamente de maneira satisfatória pelas ofensas que sobre o direito de autor devido à reprodução destinada ao uso privado.

E M.H. DELLA COSTA, Aspects juridiques de la piraterie, "rapport" apresentado à reunião da Comissão Jurídica e de Legislação da CI- 
SAC, de 20.04 a 02.05.1981, em Sydney, 12 págs. mimeografadas, recomenda que onde quer que seja possível estabelecer um "direito potencial de autor" como condição da livre fabricação, venda ou importação de fitas virgens e de aparelhos de gravação fonográfica, se estipule claramente no texto da autorização, que a retribuição cobre "as utilizações possíveis estritamente privadas", preservando o direito de autor de impedir a gravação não autorizada de suas obras, não somente "para finalidades comerciais", mas outrossim quando esta gravação é realizada "numa finalidade lucrativa, mesmo por conta de particulares e para seu gozo próprio".

Pretenderia manter, diante dessa alteração proporcionada pela evolução da tecnologia, o velho princípio de que qualquer pessoa tem o direito de reproduzir uma obra integral ou parcialmente para finalidades privadas é abrir caminho a múltiplos abusos. Não há como não reconhecer que o direito ao uso pessoal ou no âmbito familiar deve ser regulado sobre outras bases, atualizadas, mais condizentes como essa nova situação.

Partindo do princípio fundamental de "que a reprodução das obras, sejam quais forem sua maneira e sua forma, é submetida ao direito exclusivo de permissão dos autores, T.H. LIMPERG e CLAUDE JOUBERT, La Reprodution par Reprographie d'Ouvres Protégés par le Droit d'Auteur, discutido perante a Comissão Jurídica e de Legislação da Confédération Internationale des Sociétés d'Auteurs et Compositeurs (CISAC) - deduzem regra de princípio, a ser empregada em todos os casos em que não tenha lugar o exercício do direito de consentir ou de proibir: a de que o respeito aos interesses legítimos dos autores exige uma justa remuneração.

Reconhecem a impraticabilidade de qualquer proibição genérica; propōe, por isso, seja admitido reproduzir por reprografia, sem prévia autorização do autor ou de seus cessionários ou sucessores, uma obra já publicada, sob a condição todavia, de que, quem esteja qualificado para realizar semelhante reprodução respeite os direitos morais e pecuniários do autor.

\section{LEIS E JURISPRUDÊNCIA EM DIFERENTES PAÍSES}

A maioria das legislações só tem disposições relativas à locação e distribuição de filmes cinematográficos, que não sāo adaptáveis aos videocassetes.

$\mathrm{O}$ direito de distribuiçāo do produtor de videocassetes esgota-se quando ele vende cópias ao varejista. $\mathrm{O}$ aumento do volume das locaçōes e a fácil disponibilidade do produto alugado tendem a encorajar a cópia privada, fazendo com que corram o risco de prejudicar as vendas no varejo. Além disso, o vare- 
jista receberá pelas locações quantias importantes sobre as quais o produtor não tem direito algum, a menos que tenha feito estipulaçōes contratuais a respeito.

Às dificuldades inerentes ao sistema acrescenta-se mais uma: o "swapping" (troca) de videogramas entre os possuidores de exemplares.

As conseqüências da situação, indicadas no relatório A Locação dos Videogramas e dos Fonogramas redigido pela Secretaria da Federação Internacional dos Produtos de Fonogramas e Videogramas, IEPIVIDEO, a pedido da Organização Mundial da Propriedade Intelectual e da UNESCO, 38 págs. mimeografadas, janeiro de 1983, são profundas e complexas, proporcionando fortes prejuízos aos produtores de videogramas e aos titulares de direito.

"A despeito da encorajadora procura que provém do grande público, a locação corre risco de se desenvolver em detrimento da venda.

O revendedor, que ocupa uma posição chave no domínio da locação, pode alugar cassetes ou discos um grande número de vezes, o que resulta numa utilização intensiva de cada exemplar. Por outro lado, o produtor do repertório bem como todos os outros titulares de direito arriscam de não obter sua parte "legítima" do rendimento das locações, e isto pelas seguintes razões:

a. a existência da doutrina do esgotamento dos direitos;

b. o fato que as locaçōes são difíceis de administrar e que semelhante administração custaria muito"

Aponta o resultado: o locador provavelmente realizará benefícios sobre a utilização reiterada dos suportes audio visuais, benefícios sobre os quais o produtor não terá parte alguma, uma vez que ele não receberá senão o preço da primeira venda. A locação incentivará o emprego de suportes audiovisuais, o que gerará uma procura por um repertório mais amplo; mas ainda aí o produtor de videogramas não retirará os benefícios aos quais ele teria direito e que lhe permitiriam investir num novo repertório.

A concorrência entre os revendedores especializados na locação conduzirá a rebaixamentos de preços para alcançar níveis cada vez inferiores, que, a seu turno, virão mortificar ainda mais o mercado das vendas de suportes audiovisuais ao grande público, com conseqüências imprevisíveis.

Documento preparado pelas secretarias da OMPI e da UNESCO, redigido com a colaboração do sr. AGNE HENRY OLSSON Conselheiro Juridico da Divisão de Assuntos Internacionais do Ministério da Justiça, de Estocolmo, 
Reprodução Privada não Autorizada de Gravações Sonoras e Audiovisuais, de Radiodifusões e de Documentos Impressos, datado de 16.04.1984, submetido ao Grupo de Peritos sobre a Reprodução Privada não Autorizada de Gravações, Emissōes de Radiodifusão e de Documentos Impressos, que se reuniu em Genebra de 04 a 08.06.1984, 39 páginas mimeografadas, passa em resenha a legislação dos quatro países que até então haviam procurado regularmente a matéria, estabelecendo um gravame compensatório.

A Lei da República Federal da Alemanha, provê, art. 53, 5 ao direito do autor e dos artistas intérpretes ou executantes exigirem do fabricante dos aparelhos o pagamento de uma remuneração pela possibilidade que o uso dos mesmos oferece para realizar a captação de registros visuais ou sonoros ou pela sua transferência a outro registro.

Para facilitar a administração da remuneração, os organismos de arrecadação responsáveis por esta esfera constituiram uma associação conjunta, chamada ZPU (Zentralstelle für private Uberspielungsrechte), que arrecadou, em 1981, 39 milhões de marcos.

$\mathrm{Na}$ Áustria, a lei de 02.07.1980 dispõe:

"Quando, por sua própria natureza, cabe pensar que uma obra difundida pelo rádio ou fixada num registro sonoro ou visual elaborado com fins comerciais, será reproduzida mediante fixação num registro sonoro ou visual para uso pessoal, o autor terá direito a uma remuneração equitativa, sempre que os meios de gravação sonora ou visual não gravados e idôneos à mencionada gravação, ou outros meios de gravação sonora ou visual destinados a este fim (material de gravação), se distribuam dentro do país com fins comerciais, salvo quando o material de gravação não se utilize no país, ou, a ser utilizado, mencionadas cópias se destinem a uso pessoal; bastará a prova justificativa de tais circunstâncias. Para o cálculo da remuneração tomar-se-á em conta sobretudo a duração da obra. A remuneração correrá a cargo da primeira pessoa que distribua o material de gravação no país com fins comerciais"

Em 1981 a arrecadação ascendeu a cerca de seis milhōes de scillings austríacos.

Na Hungria, Decreto de 20.11.1982 do Ministério da Cultura, contém previsões análogas, e no Congo, Lei de 07.07.1982, prevê a reprodução desse gênero, destinada estritamente ao uso pessoal e privado, numa remuneração em proveito do autor, "cujo importe será proporcional aos ingressos provenientes da venda, no território nacional, dos suportes materiais virgens", a ser pago ao organismo profissional de autores. 
Adite-se que promulgada no Japão no ano de 1984 "Lei para uma medida provisória relativa aos direitos dos autores, etc., com relação ao empréstimo de fonogramas comerciais ao público", tem seu dispositivo fundamental no

"Art. 40 - 1. Uma pessoa que pretenda alugar um fonograma comercial mediante compensação ao público, deverá obter autorização para locação do mencionado fonograma comercial dos titulares de direito até um período determinado por ordem expressa do Gabinete que venha a expirar depois que o fonograma tiver sido vendido pela primeira vez neste País.

2. O ato de locação de um fonograma comercial mediante pagamento (charge) será considerado incluindo um ato de natureza econômica similar a este, seja qual for a forma ou meio em que possa ter lugar.

3. Uma pessoa que tenha obtido a autorização de que trata o $\S 1$ o mencionado pode alugar mediante pagamento ao público o fonograma comercial a que pertence a autorização, nas condições específicas na autorização".

Para W. DILLENZ, Reproduction pour l'usage privé, 10 págs. mimeografadas apresentados à reunião da CISAC já referida, não se trata, a priori, tanto de um problema jurídico quanto, mais propriamente, de um problema econômico: o prejuízo para o autor (e para os demais titulares indicados) cria-se, com efeito, mesmo no quadro de situações em que a doutrina entende que a utilização de magnetafones e de aparelhos de vídeo na esfera privada não está autorizado pelo direito de autor.

Encarece que por decisão de 18.05.1955 o Bundesgerichtshof alemão reconheceu ao autor o direito de impedir as gravações sobre fitas sonoras na esfera privada.

Seria certamente ingenuidade supor que todos os que gravam uma obra para uso particular em fita magnética comprariam esta obra registrada em fonogramas industriais se tivessem a possibilidade de reproduzí-las para seu uso.

"Sabe todo mundo que essas duas condições existiam ontem como existem hoje. A situação é portanto de natureza dinâmica: o deslocamento da reprodução do domínio industrial-comercial (onde o autor recebe uma remuneração) para o domínio privado (onde ele não a recebe)".

Nos EUA, tal como na Grã-Bretanha, no Canadá, na África do Sul e na Austrália, as exceções ao direito de reprodução reservado ao autor no que diz respeito ao uso privado ou pessoal, assumem a característica do "fair use" ou 
do "fair dealing" uso leal e de boa fé, deixando assim à jurisprudência a tarefa de determinar o alcance da expressão.

Mas é justamente esse elastério de interpretação que torna mais vulnerável o direito dos autores, dos artistas intérpretes e executantes, das gravadoras, dos produtores cinematográficos e das estações de rádio e TV.

Exemplo bem expressivo é o que foi objeto de um pleito, nos EUA, que teve intensas repercussões no mundo inteiro.

A Universal City Studios, Inc. e a Walt Disney Productions moveram ação contra Sony Corporation of America e outros, por terem gravado em fitas cassetes, por meio de aparelhos marca Betamax, alguns filmes, dos quais eram titulares dos direitos de autor.

Em primeira instância, ficou decidido ser a duplicação não autorizada de material protegido pelo direito autoral um ilícito civil e penal, mesmo quando realizada no lar, ou em domicílio particular.

Mas a decisão foi reformada, aos 19.10.1981, pela United States Court of Appeals, Ninth Circuit, que não concedeu declaração de ilicitude do comportamento tanto do cidadão privado autor das gravações, quanto dos vendedores que tinham levado a efeito gravações com finalidades demonstrativas à clientela, e, ainda, do fabricante e distribuidor dos aparelhos, responsáveis por terem tido papel determinante proporcionando o meio sem o qual o ilícito comportamento não teria sido possível.

Consideraram os juízes o procedimento do particular não ilícito, legitimando o "fair use", a atividade do utilizador da obra intelectual.

A decisão tem provocado perplexidade e reservas, acentuando II Diritto di Autore, no 2, 1981, págs. 212-215, que, o impacto tecnológico e cultural dos Betamax arrisca assim causar sérias lesões ao edifício dos direitos exclusivos.

"É certo todavia que nos próximos anos jogar-se-á o futuro do direito de autor que deverá enfrentar o desafio tecnológico, encontrado instrumentos adequados (jurídicos, políticos, culturais) não-somente para consentir a defesa de fato dos interesses dos autores, mas também para conservar um eficaz sistema de proteção jurídica a que, com o correr dos tempos, as novas exigências da cultura de massa poderiam até mesmo negar a legitimização".

\section{CONGRESSOS INTERNACIONAIS}

Os círculos internacionais já se sensibilizaram com a questão. 
Entre as Resoluções aprovadas pelo VIII Congresso da Sociedade Internacional para o Direito de autor (INTERGU), que teve lugar em Toronto, de 21 a 25.09.1981 assume relevo a que diz respeito à Reprodução privada, reclamando dos legisladores:

"1. a manutenção em princípio do direito exclusivo do autor ao aproveitamento econômico de sua obra;

2. a introdução de uma retribuição cujo cálculo será baseado no princípio da tarifa por peça

para cada aparelho que proporcione a gravação de obras protegidas pelo direito de autor,

e, ao mesmo tempo e na mesma ordem de idéias

para o material que serve de suporte audio e audiovisual para a gravação por meio destes aparelhos (fitas magnéticas principalmente os musicassetes e videocassetes virgens);

3. o aperfeiçoamento da regulamentação do processo judiciário para fazer valer os direitos dos autores, embora levando em conta os interesses dos consumidores;

4. o aperfeiçoamento da proteção pelo direito penal no caso de violação do direito de autor (incorporando-o no direito penal relativo à delinqüência econômica)"

Também a Confederação Internacional das Sociedades de Autores e Compositores, CISAC, ao encerramento de seu 33ㅇ Congresso, Roma, de 03 a 10.10.1982,

"Informada da proliferação, em numerosos países, de lojas de locação de fonogramas e videogramas cuja atividade acarreta um grave prejuízo aos interesses econômicos dos autores das obras incorporadas nesses fonogramas e videogramas;

consciente do fato que a maior parte das legislações nacionais não assegura de maneira satisfatória a proteção dos autores diante do fluxo crescente destas operações de locação;

espera vivamente, em nome de todas as associações membros, que as legislações nacionais prevejam o mais rapidamente possível disposições apropriadas reconhecendo aos autores de obras literárias e artísticas 
um direito exclusivo frente à locação de fonogramas e de videogramas que incorporem obras protegidas, ou de toda forma análoga de aproveitamento a fim de que seja plenamente assegurada a indispensável proteção dos interesses dos autores frente a esta nova modalidade de utilização de suas obras"

ditou "Resolução" relativa a Locação de Fonogramas e Videogramas, convidando "seus órgãos constitutivos a tomar todas as medidas apropriadas para colocar suas sociedades membros em medida de defender e gerir os direitos de locação dos autores tão logo uma legislação apropriada tenha sido adotada na matéria" (Bulletin du Droit d'Auteur da Unesco, vol. XVIII, no 1, 1983).

No IX Congresso da INTERGU e IV Conferência Continental do Instituto Interamericano do Direito de Autor, IIDA, (30 de outubro a 04.11.1983, Santiago, Chile), entre outras declarações, foi aprovada a de que:

"Deve pagarse una suma adecuada a los autores y otros titulares de derechos intelectuales por la reproducción privada y el arrendamiento de video programas, fonogramas y audiovisuales"

Justificou-se:

A constante evolução da tecnologia da reprodução para uso pessoal de obras visuais e audiovisuais exige dos legisladores uma tomada de posiçāo em favor dos autores, dos artistas e outros titulares de direitos intelectuais, abandonando o critério de permissibilidade para a obtenção de cópias para uso pessoal, visto que a atual possibilidade de multiplicar ilicitamente os exemplares, prejudica enormemente os titulares de direito.

As únicas vias atualmente plausíveis para compensar tão sérios danos, são as indicadas pelas legislações da Áustria e da Alemanha, critérios que foram adotados no projeto de lei do CNDA, do Brasil, introduzindo o pagamento de remuneraçōes compensatórias sobre a importação, fabricação e venda de fitas virgens.

Tanto a Organização das Nações Unidas para a Educação, a Ciência e a Cultura, Unesco, com sede em Paris, quanto a Organização Mundial da Propriedade Intelectual, Genebra, se empenharam no estudo do problema da "Reprodução Privada não Autorizada de Gravações, Emissōes de Radiodifusão e de Documentos Impressos", reunidos, na Capital suíça, de 12 a 16.12.1983, um comitê de peritos que examinou o aludido relatório formulado a pedido de ambas as organizações pela Federação Internacional dos Produtores de Fonogramas e Videogramas (IPFIVIDEO) a respeito dos problemas decorrentes, no plano do direito autoral da locação de gravações de obras protegidas e sua distribuição. 
Depois de terem convidado os Estados signatários das Convenções de Berna e Universal a apresentarem observações, promoveram, de 04 a 08.06 do ano de 1984 a reunião em Genebra de um grupo de peritos, que não tiveram, ao concluir seus trabalhos, outro alvitre senão sugerir a ambas as instituições "que continuem a estudar a incidência sobre os direitos conexos, da gravação e da reprodução reprográfica para fins privados de obras protegidas e de reproduções protegidas pelos direitos conexos, e que elaborem princípios comentados de proteção ao direito de autor e aos direitos conexos nesse domínio".

\section{A SITUAÇÃO EM NOSSO PAÍS}

Não prevê a Lei no 5.988, de 14.12.1973 a locação ou o empréstimo remunerado de obras artísticas ou literárias, o que é tanto mais lamentável porquanto o Projeto BARBOSA-CHAVES, depois de ter consignado no art. $31 \mathrm{e}$ seus parágrafos que a aquisição do original ou de um exemplar de uma obra não confere aos compradores o exercício de qualquer atributo pecuniário do direito de autor, havia considerado expressamente no art. 32 o direito à locação de obra ou de reprodução, definindo-o com o de entregar o uso e gozo de uma obra ou de reproduções da mesma, por tempo determinado, mediante remuneração, sem prejuízo dos direitos de autor. Deixava claro, assim, que a ulterior cessão em locação também depende de expresso consentimento do titular da prerrogativa.

Embora não transladado para a Lei no 5.988 , o critério pode ser deduzido dos termos genéricos empregados pelo art. 38 , que incorporou a idéia contida no aludido 31 , sendo que o art. 3 manda que se interpretem restritivamente os negócios jurídicos sobre direitos autorais.

Qualquer aproveitamento não consentido de obra alheia fica sujeito às sanções previstas no art. 123, autorizando a apreensão dos exemplares reproduzidos ou a suspensão da divulgação ou utilização da obra, sem prejuízo do direito à indenização de perdas e danos.

Não considera o art. 49, II, ofensa ao direito de autor a reprodução, em um só exemplar, de qualquer obra, contanto que não se destine à utilização com intuito de lucro.

Dispositivos desse tipo, por bem intencionados que sejam, proporcionam, no mundo inteiro, milhões de violações, muitas vezes inconscientes, ao direito de autor, no âmbito literário e científico, por meio de xerox, e, no musical e artístico, através dos cassetes e videocassetes.

Essa situação não podia deixar de produzir seu impacto no texto da referida lei, que dez anos foram suficientes para tornar, quanto a esse ponto, completamente obsoleta, exigindo os aparelhos de gravação e multiplicação eletrô- 
nica ao alcance de todos, diz bem, HENRIQUE GANDELMAN,

"aprofundar mais a defesa destes direitos intelectuais, no próprio interesse da preservação da liberdade de expressão, um dos direitos fundamentais do homem. Uma sociedade só é livre, quando seus criadores intelectuais - escritores, pensadores, cientistas, educadores, artistas, etc. são realmente agasalhados pelo Direito.

O videocassete é, sem dúvida, a primeira arma pessoal - e digamos, imaterial - que, involuntariamente, pode tornar qualquer cidadão 'autor' de um ato ilegal: a pirataria doméstica".

Mesmo nos casos, portanto, em que não existe intenção maliciosa de tirar vantagens mediante aproveitamento do trabalho alheio, ou de prejudicar os legítimos titulares do direito, é generalizado o reconhecimento do prejuízo ocasionado aos autores, intérpretes e empresas produtoras de discos e filmes pelas gravaçōes levadas a efeito individualmente, em enorme escala.

As restrições aos direitos de autor, contidas no art. 49 da Lei no 5.988 precisavam mesmo passar a ser consideradas na conformidade das conquistas técnicas dos novos tempos, para serem compatibilizadas com o espírito do art. $153, \S 25$ da Constituição, que reconhece pertencer aos autores de obras literárias, artísticas e científicas o direito exclusivo de utilizá-las.

Define aquela lei o fonograma (cassete) como "a fixação, exclusivamente sonora, em suporte material" e o videofonograma (videocassete) como "a fixação de imagem e som em suporte material" (art. 4으, nos VII e VIII).

O Supremo Tribunal Federal pela sua Primeira Turma já teve duas manifestações, dando por derrogados os incisos I e IV do art. 666 referido, e, conseqüentemente, a letra a do inciso I do art. 49 da Lei no 5.988 , que não considerava ofensa aos direitos do autor a reprodução de trechos de obras já publicadas ou, ainda que integral, de pequenas composições alheias no contexto de obra maior.

A primeira foi no RE no 75889, em que o Ministro ANTONIO NEDER reconheceu que a reprodução deve ser feita nos termos expressos da aludida regra constitucional,

"Ou seja, mediante pagamento, ao autor da obra, do quantum correspondente à vantagem, ou ganho, ou lucro, que obteve a pessoa que reproduziu trecho de trabalho literário, artístico ou científico".

$\mathrm{Na}$ segunda, RE 83294 reiterou essa posição o relator Ministro BILAC PINTO. 
Uma incursão a que procedeu pelo direito comparado, revelou

"que as limitadas regras de proteção contidas no CC haviam sido superadas pelo amplo universo que a esse direito foi aberto pelo desenvolvimento técnico dos velhos meios de comunicação: pela invenção do rádio, da televisão, das fitas gravadas para registro do som e dos videotapes para a simultânea gravação de imagem e do som, dos modernos aparelhos de reprografia, dos computadores, da utilização de fotografias nos novos e velhos veículos de difusão da imagem e das técnicas atualizadas de proteção da criação artística, compreendendo a escultura, a pintura, a gravura, o desenho, a música, etc., o que alargou e diversificou o elenco dos direitos autorais cobertos pela proteção legal.

As múltiplas formas pelas quais as obras literárias - em prosa e verso - passaram a ser parcial ou totalmente utilizadas em livros, em espetáculos públicos, em fonogramas, em peças teatrais, em filmes, em programas de rádio e televisão, ou mediante aparelhos de reprografia, revelou que o direito exclusivo do autor de reproduzir sua obra já não dava a este proteção legal contra as modernas formas de violação dos direitos de autor. Essa a razão pela qual foi ampliada a definição de direito autoral".

\section{O CONTROLE DE VIDEOCASSETES, A RESERVA DE MERCADO E O REGISTRO DE GRAVADORAS PELAS RESOLUÇŌES CON- CINE NoS. 97, 98 E 99}

A matéria está regulamentada através dessas resoluçōes.

Pela de no 97, de 29.07.1983, que "Institui etiqueta de controle e estabelece obrigatoriedade de colagem, no Brasil, para filmes gravados em videocassetes" (DO 29.08.1984),

"CONSIDERANDO não haver distinção legal entre obras cinematográficas quanto à técnica de reprodução, equiparando, a legislação, as produzidas ou copiadas pelos processos convencionais àquelas que 0 foram eletronicamente, como dispōem o inciso VI do art. 6을 Lei 5.988, de $14,12,1973$, e o parágrafo único do art. $1^{\circ}$ do Decreto-lei 1900 , de 21.12.1981;

CONSIDERANDO que o videocassete é uma fita magnética acondicionada em caixa plástica de dimensōes padronizadas, apta a fixar e reproduzir obra cinematográfica; 
CONSIDERANDO as diretrizes de ação comum, relativas ao assunto, fixadas por representantes da Diretoria de Comércio Exterior do Banco do Brasil S.A., da Secretaria da Receita Federal, da Divisão de Censura e Diversões Públicas, do Conselho Nacional de Direito Autoral, da Empresa Brasileira de Filmes S.A.-EMBRAFILME e deste Conselho;

criou, para aposição em fitas gravadas em videocassete, etiqueta de controle emitida e fornecida, exclusivamente, pela EMBRAFILME, só admitindo sejam comercializadas no País fitas gravadas em videocassete com a respectiva etiqueta, na forma da mesma Resolução.

Formula os requisitos para que as matrizes de obras cinematográficas destinadas à reprodução em fitas de videocassete sejam previamente registradas na EMBRAFILME, a requerimento do interessado.

"Só serão liberadas etiquetas de controle e fitas referentes a matrizes registradas na forma do item III, procedendo, a EMBRAFILME, sempre a requerimento do interessado.

a) no caso de serem diversos os requerentes mencionados neste e no item III, o deferimento da liberação das etiquetas ficará condicionado à prévia comprovação da titularidade a que se refere a alínea "c" do item III;

b) o requerimento especificará o número de cópias, de fitas gravadas em videocassete podendo a EMBRAFILME requisitá-las, correndo as despesas de frete e seguro, quando houver;

c) a aposição de etiquetas competirá à EMBRAFILME, que, contudo, a seu critério, poderá fornecê-las ao interessado para que o faça diretamente.

Não serão fornecidas etiquetas para fitas gravadas em videocassetes copiadas no exterior, incumbindo ao requerente comprovar, de plano, a copiagem no Brasil, instruindo o requerimento a que se refere o item anterior com as notas fiscais emitidas por empresa registrada na forma das normas vigentes, emanadas do CONCINE.

As etiquetas, uma para cada cópia, e dotadas de numeração seqüencial correlata ao número de registro da matriz correspondente, serão afixadas no videocassete e obedecerão ao modelo anexo à mesma Resolução.

A EMBRAFILME poderá cobrar pelo serviço de registro de matrizes e fornecimento de etiquetas de controle. 
a) os preços serão fixados pelo CONCINE, por proposta da EMBRAFILME;

b) os preços assim fixados serão cobrados por etiquetas e pagos no ato dos requerimentos previstos nos itens III e IV

Seguem-se disposiçōes contendo sanções: as do inciso X do art. 36, do Dec.-lei 43, de 18.12.1966, com a redação do art. $2^{\text {O }}$ da Lei 5.848, de 07.12.1972, sujeitando a multa de 50 a 100 vezes o maior valor de referência vigente no Distrito Federal, apreensão, multas e interdições, principalmente em caso de reincidência.

Esta Resolução foi mandada aplicar à comercialização, locação e sublocação de quaisquer videocassetes gravados pela de $\mathrm{n}$ - 98, de 25.11.1983, item no XIV, que cria reserva de mercado para videocassete, estabelece o percentual mínimo de obras cinematográficas gravadas nesse suporte e determina o registro de seus distribuidores, a ele sujeitando "as sociedades comerciais ou civis, com ou sem fins lucrativos, regularmente constituídas, que tenham tal atividade como objeto, ainda que em caráter secundário".

Obriga os distribuidores que forneçam videocassetes a intermediários para revenda, locação ou sublocação; ou que exerçam intermediação na compra e venda, locação ou sublocação a oferecer sobre títulos e cópias que tenham em carteira, no mínimo: 1) $25 \%$ de títulos de obras cinematográficas nacionais; 2) $25 \%$ de videocassetes gravados com obras cinematográficas nacionais.

Os distribuidores que revendam, loquem ou subloquem ao consumidor deverão, por sua vez, oferecer no mínimo $25 \%$ de videocassetes gravados com obras cinematográficas nacionais, sobre o total de cópias que tenham em carteira, estendendo essa obrigatoriedade a todos os estabelecimentos de uma mesma pessoa jurídica.

"As etiquetas de que trata a Resolução CONCINE no 97, de 29.07.1983, não serão concedidas a distribuidores cuja atividade se compreenda exclusivamente no no 3 da alínea "a" do item $I$, e, aos demais, só serão fornecidas se comprovada a proporcionalidade disposta nos itens II, III e VI, observado o disposto no item $X$.

O requerimento de registro de títulos e de etiquetas para obras estrangeiras deverá contemplar títulos nacionais e videocassetes gravados com essas obras, na proporção disposta do item II c/c item VII".

Seguem-se especificações dos dados que os distribuidores de videocassetes deverão manter, atualizados diariamente, em seus estabelecimentos, sançōes e respectivas normas de autuação. 
Pela Resolução no 99, de 25.11.1983, finalmente, criou o CONCINE o - Registro de sociedades comerciais ou civis, com ou sem fins lucrativos, prestadores de serviços de gravaçōes de videocassetes e de produção de matrizes "masters" - em "video-tape", - e sujeita às sanções do inciso X do Dec.-lei no 43 , de 18.11.1966, com a redação do art. 20 da Lei no 5.848 de 07.12.1972 aquele que exercer, sem estar inscrito no registro referido, quaisquer das atividades de produção de matrizes em videotape para reprodução em videocassetes de obras cinematográficas produzidas originariamente sobre qualquer suporte e segundo qualquer tecnologia, e, ainda, gravação de videocassetes a partir de matrizes em videotape, sujeitando o infrator a multa que variará de $1 / 3$ do valor de referência MVR, vigente no Distrito. Federal na época da autuação, a 100 vezes o mesmo valor.

Todo esse conjunto de providências, - justas e necessárias - já submetem, como se vê, os produtores de videocassetes, e, de maneira particular, os videoclubes, distribuidores, locadores e revendedores dessas obras a uma vigilância e fiscalização rigorosíssima, abruptamente implantada da noite para o dia.

Mas essa defesa, de resto indispensável do direito de autor, tanto no setor público, quanto no privado, não pode consistir numa perseguição cega e indiscriminada de toda projeção de videotapes.

Tais são os casos das obras caídas em domínio público e as que nele foram integradas pela lei brasileira, como são as divulgadas em países que não participam de tratados com o Brasil e não dêem às obras de autores pátrios o tratamento nacional, nos termos do art. 48, no III, da Lei no 5.988, cuja reprodução é perfeitamente lícita, até mesmo para fins de comercialização, como não é contrária à lei a reprodução de obras cujos direitos não sejam protegidos nos países de origem, de acordo com a legislação local ou internacional aí vigente, ou por falta de registro ou por qualquer outro motivo.

Diante da notória impossibilidade, que se espera venha a terminar em dia não muito distante, dos produtores nacionais suprirem as necessidades do mercado brasileiro, ou generalizando mais, dos mercados dos países em desenvolvimento se auto-suprirem, não há como admitir que o desfraldamento da bandeira da legalização dos direitos autorais relativos aos videocassetes venha, num exagero e numa inversão de posiçōes, levar de roldão a própria incipiente produção nacional, que vê com grande esperança possibilidades de realização nesse novo e promissor setor, levantando-se contra qualquer pretensão de estabelecimento de monopólio de potências multinacionais.

A proteção da obra cinematográfica não pode acolher-se sob a umbrela do tratamento dispensado aos autores e artistas intérpretes estrangeiros, domiciliados no exterior, que obedece a uma filosofia, a uma estrutura, a princípios completamente diferentes. 
A razão consiste em que a tendência do direito de autor propriamente dito é expansionista por sua natureza: uma canção, um drama, uma poesia, têm mais arte do que técnica, integram a cultura, que não suporta barreiras.

O disco, como o filme e pois, o cassete, o videocassete e similares, como o livro, em sua expressão material, são mais indústria e comércio, por valiosa que seja a obra que consubstanciam: a entrada da produção estrangeira não pode ser demasiadamente facilitada, tem que sofrer freios e contrapesos, como ocorre em todas as nações adiantadas.

A não ser assim o domínio avassalador da produção industrial das grandes potências não teria limites: sufocaria, com o seu imenso poderio econômico e industrial, qualquer veleidade da afirmação da indústria nacional. Satisfeito o mercado do próprio país desenvolvido, obtido aí todo o lucro, poderiam suas indústrias exportar com um mínimo de vantagem: cem cruzados sobre cada videocassete vendido entre o Amazonas e o Chuí seria lucro, rebaixando as despesas de produção, sem qualquer sacrifício suplementar, mas com imolação definitiva da produção local.

Dissertando a respeito da proteção concedida ao fonograma - e a argumentação aplica-se perfeitamente ao videograma - lembra JOSÉ DE OLIVEIRA ASCENSÃO, Direito Autoral, Rio, Forense, 1980, pág. 278, que sua proteção não vai desenvolver-se em termos da atribuição de direitos sobre o suporte material. Ninguém nega que sobre este recai uma propriedade regida pelas regras comuns, tendo aqui plena aplicação analógica da Lei 5.988.

O que se sujeita a um regime particular é a utilização da coisa incorpórea mediante a utilização da coisa corpórea:

"O objeto do direito é pois a própria coisa, muito embora este direito nada tenha que ver com a propriedade dessa coisa. Atende-se a um tipo de particulares utilizaçōes, em vez de se atender à universalidade das utilizaçōes, como na propriedade".

\section{A ÚNICA SOLUÇĀo PLAUSíVEL: REMUNERAÇĀo PELA "PO- TENCIALIDADE' DE GRAVAÇÃO DE OBRAS PROTEGIDAS PE- LO DIREITO AUTORAL. UM PROJETO DE LEI BRASILEIRO}

Estamos, pois, diante do sentimento generalizado de que há necessidade de uma atualização das soluções do problema do reconhecimento; pelo Supremo Tribunal Federal, da revogação do aludido inciso I do art. 49 da Lei no 5.988; da regulamentação apenas parcial da matéria através de Resoluções do CONCINE, gravitando em torno de um vazio legislativo e gerando insegurança e perplexidade, bem patenteados pela presente consulta. 
Uma situação dessa natureza não faz vislumbrar outra solução senão a decorrente de uma providência legislativa, diante do risco que correm, numa situação de fato consolidada há vários anos, gerando senão um como que direito adquirido, pelo menos uma situação indiscutível de pré-uso não só dos vendedores (donos de lojas), dos locadores, dos clubes de videocassetes e videodiscos, como também dos próprios locatários dessas fitas, que já formam um mercado muito respeitável e cobiçado.

Há que estabelecer distinção entre duas situaçōes diferentes: a dos vendedores, as lojas e os locadores dos videocassetes, que adquirem e vendem ou alugam material legalmente adquirido, sem nada pagarem de direitos autorais por não lhes ter sido exigido ainda esse pagamento, mesmo porque não saberiam a quem efetuá-lo nem em que base; - e a dos que não se contentam com um só exemplar, para colocar à disposição da demanda de seus clientes, e os multiplicam por sua própria iniciativa, sem se munirem da necessária licença, potencializando, por essa forma abertamente ilícita, os prejuízos dos fabricantes, dos autores e dos artistas intérpretes e executantes.

$\mathrm{Na}$ mesma situação encontram-se os locatários desses tapes: têm direito de assistir uma ou mais vezes ao espetáculo contido no videocassete. Mas somente quando tiram mais de um exemplar estarāo infringindo o aludido art. 49, II, da Lei 5.988, agravando seu "crime" ao comercializarem exemplares.

Mas o simples fato dos locadores de videocassetes não terem condiçōes de retribuírem os produtores, os autores e os artistas pelos direitos autorais usufruídos os deixam em posição incômoda, e a presente consulta é uma demonstração de sua disposição de encontrar uma solução para o problema.

A dificuldade - insista-se - não é peculiar ao nosso país.

Uma reportagem publicada na revista norte-americana Video Review, de maio de 1984 é extremamente ilustrativa para demonstrar que o mesmo problema, com características ainda mais frisantes, se apresenta nos EUA. Depois de aludir a um julgamento da Suprema Corte, admitindo como legal o "tape" doméstico, refere-se a um projeto de lei em andamento no Congresso para definir quem controlará os aluguéis de programas para computadores domésticos, se os produtores de fitas originais de videocassetes e, em escala muito menor, videodiscos ou se os proprietários de lojas.

Enquanto que os produtores qualificam esta reivindicação como luta para uma justa alteração de vendas, os proprietários de lojas entendem não passar isto de uma ameaça ao princípio da "venda em primeira mão", na conformidade da Copyright Law, $\S 109$, a, que consiste em poder o possuidor de uma cópia particular ou gravação fonográfica legalmente produzida, ou qualquer pessoa 
por ele autorizada, sem permissão do titular do direito de autor, vender ou de outra forma dispor da posse dessa cópia ou gravaçāo fonográfica.

A reportagem invoca o caso das locadoras de automóveis: a GM vende seus carros para a AVIS; esta os aluga para o consumidor, não tendo que pagar nada do que recebeu à GM.

O princípio legal que permite às lojas e à AVIS comprarem os produtos e os alugarem em seguida, sem terem que reembolsar nada aos fabricantes é chamado de "venda em primeira mão", que faz parte das leis instituídas no século XIX. Em 1976 o Congresso reafirmou o princípio e o codificou no parágrafo 109 da lei: quando o proprietário transfere a posse de uma determinada cópia ou gravação fonográfica de uma obra, a pessoa que o adquiriu tem o direito de vender, alugar ou destiná-la a outro fim qualquer.

Mas reconhece que o campo do videocassete não é igual ao do automóvel: as empresas que se dedicam à locação de carros absorvem uma percentagem mínima do produto fabricado, ao passo que os fãs preferem alugar ao invés de comprar o cassete numa percentagem calculada em $95 \%$ dos casos.

"Em outras palavras, os produtores (ou os titulares de direitos autorais) destes cassetes só têm lucro quando os vendem às lojas ou aos poucos făs que se interessam em comprá-los, portanto, só ganham uma pequena porção do montante lucrado destes filmes em V.C..."

Por isso, os produtores de Hollywood, a fim de serem mais compensados, esforçam-se por obterem seja revogado o princípio de "venda em primeira mão", para que se aplique ao vídeo o que eles chamam de justa alteração de marketing.

"Se esta alteração passar, os produtores controlariam os aluguéis dos V.C. As conseqüências seriam muitas, algumas boas, outras ruins para os compradores e locadores de V.C."

A reportagem revela ainda duas outras preocupações: com os produtores controlando os aluguéis de videocassetes seria possível que alguns filmes, incluindo grandes êxitos como "Flashdance" ou "The Complete Beatles", não estivessem disponíveis para alugar, forçando os fãs a comprar os cassetes.

Além disso, o projeto poderia afetar muito a disponibilidade das fitas: títulos menos populares poderiam ser retirados das locadoras porque os estúdios não só "empurrariam" títulos mais novos para gerar maiores lucros, como também, acrescentamos nós, forçariam a compra dos videocassetes de menor sucesso a preços mais baixos, saturando assim o mercado de produto inferior, tal como ocorre atualmente com os filmes cinematográficos, principalmente nas 
pequenas cidades do interior que dispõem de um só salão de cinema, implicando em menor número de tapes à escolha.

Com Hollywood tendo participação impositiva unilateralmente, e, pois, arbitrária, nos lucros dos aluguéis de videocassetes, receiam os proprietários que milhares de lojas de vídeo acabem em concordata - o que está prestes a ocorrer também no Brasil, conseqüência fatal do cumprimento integral do aludido Protocolo de Intençōes - ficando conseqüentemente em menor número os pontos de locação de tapes.

Ao que parece o Governo Reagan tenderia a revogar o princípio da venda em primeira mão, entendendo, porém, que só deve aplicar o critério aos novos tapes, sem uso retroativo. Os proprietários de lojas continuariam a controlar os aluguéis dos tapes já existentes em seu inventário, e os produtores, todos os novos lançamentos em tapes publicados após a aprovação da proposta de alteração de venda em primeira mão.

Por aí se percebe que a atitude tomada no Brasil pelos produtores cinematográficos e detentores estrangeiros de direitos sobre obras cinematográficas sob a forma de videocassete obedece a uma políica e a um plano de ação bem estudado e melhor conduzido em todas as partes do mundo.

A solução do problema transcende, pois, de muito, o âmbito desta consulta, para abranger praticamente todas as manifestações artísticas e culturais veiculadas pelos modernos meios de comunicação de massa.

As exigências do ensino, da pesquisa e da cultura, ao ritmo trepidante da vida moderna, que não permite sequer um momento de pausa para verificar se existe, quem é, onde está, o titular do direito, tornam cada vez mais utópico e distante o dogma, até há poucos anos indiscutível, da exigência do consentimento do autor para qualquer aproveitamento de sua obra.

Como conciliar os interesses do criador com os da coletividade?

Aí está, sem dúvida, um árduo teste, não apenas para as legislações internas de cada país, como também para as grandes convençōes internacionais, que já não podem ignorar o problema, verdadeira pedra-de-toque das concepçōes teóricas e da aplicação prática dos princípios, encruzilhada, ponto de encontro de todas as construções científicas e legislativas, colocando frente a frente conceitos antigos como o do consentimento do autor e do intuito de lucro, e novos, como a licença obrigatória e a licença global.

Atente-se a que, se nos Estados Unidos, a Lei estabelece o princípio de "venda de primeira mão", considerando certamente o perigo dos produtores 
pretenderem controlar os aluguéis dos videocassetes e todos os inconvenientes e transtornos que daí possam decorrer, e se a Suprema Corte admitiu a legalidade de cópias de vídeo para uso privado, não seria justo conceder aos produtores cinematográficos e detentores norte-americanos de direitos dessas obras, privilégios, no Brasil, que eles nem sequer alcançariam em seu próprio país, $\mathrm{o}$ que desde logo exclui qualquer veleidade dos produtores brasileiros alcançarem, lá, reciprocidade de tratamento.

Mas isso não impede o reconhecimento da necessidade de se proceder à cobrança pela utilização de qualquer texto reproduzido mediante aparelhos gravadores, ressalvando-se expressamente as poucas exceções que a regra comporta.

Vem em seguida o como há de se chegar ao único caminho plausível: a licença obrigatória ou licença legal, preconizada em novembro de 1973 por T. LIMPERG, em colaboração com CL. JOUBERT, no rapport apresentado à Comissão Jurídica e de Legislação da Confédération Internacionale des Sociétés d'Auteurs et Compositeurs (CISAC).

São justamente esses gravíssimos problemas que visa solucionar Anteprojeto de lei, propondo a remuneração dos autores e artistas intérpretes e/ou executantes pela simples possibilidade de reprodução de obras em fitas magnéticas de áudio ou de vídeo, que foi apresentado ao Conselho Nacional de Direito Autoral na sessão do dia 14.04.1982, consubstanciado em quatro dispositivos principais, versando respectivamenrte o princípio básico, a indicação do momento em que torna-se devida a remuneração e como será feita.

Atendo-se exclusivamente às gravações começa propondo:

"Art. 1‥ Os titulares de direitos de autor e dos que lhes são conexos, cujas obras, produções, execuções e interpretações sejam suscetíveis de reprodução em fitas magnéticas de áudio ou de vídeo, terão direito a uma remuneração de natureza autoral, como compensação à possibilidade de utilização de seus bens intelectuais, procedida em função do disposto no inciso II do art. 4 da Lei no 5.988 , de 14.12.1973.

Parágrafo Único. As fitas magnéticas a que se refere este artigo são aquelas não gravadas, contidas em magazines (vídeo e áudio cassetes)".

A proposição está em consonância com os reclamos da justiça e da doutrina, que proclama que reconhecer ao autor (e ao artista intérprete-executante) um direito, para depois abandoná-lo à própria sorte, não constitui qualquer solução.

E também com a orientação das legislações mais adiantadas, como as da Áustria e da Alemanha, com proposições, porém, melhor elaboradas. 
Harmoniza-se, além disso, com o espírito da Lei no 4.944, de 06.04.1966, que "Dispõe sobre a proteção a artistas, produtores de fonogramas e organismos de radiodifusão, e dá outras providências", completando-a, mesmo, dentro de sua estrutura.

Com efeito, reserva o art. $1^{\circ}$ exclusivamente ao artista, seu mandatário, herdeiro ou sucessor, a título oneroso ou gratuito, impedir a gravação, reprodução, transmissão ou retransmissão, pelos organismos de radiodifusão, ou qualquer outra forma, de suas interpretaçōes e execuçōes públicas para as quais não haja dado seu prévio e expresso consentimento.

Correlatamente, dispõe o art. $4^{\circ}$ caber exclusivamente, ao produtor de fonogramas autorizar ou proibir-lhes a reprodução, direta ou indireta, a transmissão, a retransmissão pelos organismos de radiodifusão e execução pública por qualquer meio, concedendo o art. 5, com exclusividade, aos organismos de radiodifusão autorizar ou proibir a retransmissão, fixação e reprodução de suas emissões, bem como a comunicação ao público, pela televisão, de suas transmissões em locais de freqüência coletiva.

Dá, ainda, cumprimento às determinações contidas na Convenção sobre Proteção de Produtores de Fonogramas, contra a Reprodução não Autorizada de seus Fonogramas, concluída em Genebra a 29.10.1971, que entrou em vigor, para o Brasil, em 28.11.1975, e promulgada pelo Decreto n- 76.906, de 24 de dezembro seguinte.

Nos termos do art. $2^{\circ}$, cada Estado Contratante se compromete a proteger os produtores de fonogramas que são nacionais dos outros Estados Contratantes contra a produção de cópias feitas sem o consentimento do produtor e contra a importação de tais cópias, quando a produção ou a importação é feita tendo em vista uma distribuição ao público, assim como a distribuição das referidas cópias ao público.

Deixa claro ainda o art. 60 que nenhuma licença obrigatória poderá ser prevista salvo se forem cumpridas as seguintes condiçôes:

“a. a reprodução destinar-se-á ao uso exclusivo do ensino ou da pesquisa científica;

b. a licença somente será válida para a reprodução no território do Estado Contratante cuja autoridade competente outorgou a licença e não se estenderá à exportação de cópias;

c. a reprodução, feita em conformidade com a licença, dará direito a uma remuneração eqüitativa, que será fixada pela referida autori- 
dade levando em conta, entre outros elementos, o número de cópias que serão realizadas."

\section{QUANDO E COMO SERÁ COBRADO O NOVO DIREITO}

Propõe ainda o aludido Anteprojeto:

"Art. 2‥ A remuneração tornar-se-á devida quando do surgimento do fato gerador do Imposto sobre Produtos Industrializados (IPI), na saída do estabelecimento industrial, pelo fabricante, ou no ingresso da fita magnética no país, pelo importador.

Parágrafo único. A remuneração é exigível ainda nos casos de imunidade, isenção ou não incidência do tributo aludido neste artigo."

Tem pois, o mérito de deixar bem determinado o momento em que a remuneração deve ser paga, evitando delongas e dúvidas.

Harmoniza-se com o disposto no art. 83 de Lei no 5.988, introduzido pela Lei no 6.800, de 25.06.1980, determinando que "os cassetes, cartuchos, discos, videofonogramas e aparelhos semelhantes, contendo fitas de registro de som gravadas, não poderão ser vendidos, expostos à venda, adquiridos ou mantidos em depósitos para fins de venda, sem que em seu corpo conste, em destaque e integrando-o de forma indissociável, o número de inscrição no Cadastro Geral de Contribuintes - CGC, do Ministério da Fazenda, da empresa responsável pelo processo industrial de reprodução da gravação."

A matéria foi objeto de regulamentação pela Resolução no 23 , de 1981 , do CNDA, que "Estabelece normas para identificação de reproduções de videogramas e fonogramas e para contabilização de direitos fonomecânicos nas empresas produtoras, editores e associações."

Concilia-se, finalmente, com as Convençōes internacionais que cuidam de amparar o criador intelectual contra o uso indiscriminado da obra sob a cobertura do malsinado "uso pessoal". Assim, a revisão da Convenção de Berna, levada a efeito em Paris, em 1971, aprovada pelo Decreto Legislativo no 55, de 28.06.1975 e promulgada pelo Decreto no 76.905, de 24.12.1975, estabelece,

"Art. 99. 1. Os autores de obras literárias e artísticas protegidas pela presente Convenção gozam do direito exclusivo de autorizar a reprodução destas obras, de qualquer modo ou sob qualquer forma que seja.

2. As legislações dos países da União reserva-se a 
faculdade de permitir a reprodução das referidas obras em certos casos especiais, contanto que tal reprodução não afete a exploração normal da obra nem cause injustificado prejuízo aos interesses do autor.

3. Qualquer gravação sonora ou visual é considerada uma reprodução no sentido da presente Convenção."

Tem pois razão a "Justificação" do Anteprojeto ao sustentar serem as expressōes grifadas inconciliáveis com a ampla autorização do inciso II do art. 49 da Lei no 5.988:

"Efetivamente, a cópia das obras procedidas com o uso dos chamados 'cassetes', de áudio ou de vídeo, afeta a exploração das mesmas e causa prejuízo a seus autores.

Não mais se trata de uma, ou de raras pessoas que, no recesso do lar e a duras penas, copiam à mão os 'Lusíadas'. Trata-se de premir um botão e copiar, do rádio, de um disco ou do aparelho de televisão, uma música, uma sinfonia ou uma obra cinematográfica. São milhares, são milhöes de pessoas fazendo isso a cada dia, lesando enormemente os direitos de autores, intérpretes, executantes e produtores.

Como, então compatibilizar-se o direito interno com o imperativo que dimana do direito convencional e da própria Constituição Federal?

A solução não pode residir, obviamente, na proibição de reproduzir, pois os aparelhos de reprodução e os suportes (cassetes virgens) existem e não constituem, em si, algo ilícito. Ilícita seria a cópia de obra protegida.

A saída estaria na solução que deu o próprio Supremo Tribunal Federal no caso da norma do inciso I do art. 666 CC: a reprodução é consentida, como uma espécie de licença legal, mas o autor tem direito a uma remuneração por tal uso."

O Anteprojeto brasileiro evita, além disso, a contradição que o dispositivo apresenta, com outros do mesmo diploma, que, não só no art. 29 , reserva ao autor o direito de utilizar, fruir e dispor de obra literária, artística ou científica, bem como o de autorizar sua fruição por terceiros no todo ou em parte, como ainda submete, no art. 30 à autorização do mesmo "qualquer forma de sua utilização". 
Enumera, ao lado da edição; da tradução para qualquer idioma; da adaptação ou inclusão em fonograma ou película cinematográfica,

"IV a comunicação ao público, direta ou indireta, por qualquer forma ou processo, como: a. execução, representação, recitação ou declamação; b. radiodifusão sonora ou audiovisual; c. emprego de altofalante, de telefonia com fio ou sem ele, ou de aparelhos análogos; d. videofonografia.

Parágrafo único. Se essa fixação for autorizada, sua execução pública, por qualquer meio, só se poderá fazer com a permissão prévia, para cada vez, do titular dos direitos patrimoniais de autor."

Estão assim amadurecidos os tempos para a adoção da medida em boa hora alvitrada, e que irá, ao mesmo tempo que repara uma grave injustiça, proporcionar aos autores, artistas intérpretes e demais titulares um abundante fluxo de proventos compensadores e dignificadores de seu trabalho.

Na pesquisa dos princípios jurídicos aplicáveis, combina M.H. DELLA COSTA a "responsabilidade objetiva" e o "risco criado" com o fato lícito não necessariamente prejudicial,

"que no entanto cria esta responsabilidade e não diante de um autor determinado de obras intelectuais, mas face à "comunidade dos autores" - defrontamo-nos com o segundo plano de ilicitude que é subjacente à legalidade do comércio de material virgem e de aparelhos gravadores: o fato de facilitar a pirataria ao mais alto grau e ao alcance de todos."

Entre as alternativas que a solução desse problema levanta, opta o Projeto pela de consagrar o "direito potencial", com as reservas necessárias que permitam, num segundo tempo, diante do fato concreto da gravação ilegítima, exigir a reparação correspondente e outras consequiências da violação do direito de autor.

Adita o art. 3 do Anteprojeto que a cobrança "será feita coletivamente, beneficiando todos os titulares de direitos autorais sobre fixações sonoras e audiovisuais, através do Escritório Central de Arrecadação e Distribuição (ECAD), a que se refere o art. 115 da Lei no 5.988, de 14.12.1973”.

Outorga o art. 4º, competência ao Conselho Nacional de Direito Autoral para homologar o valor da remuneração e aprovar os critérios de distribuição de seu montante entre os titulares de direitos autorais, através das associações a que alude $o$ art. 103 da referida Lei. 
A falta de convenção entre as associaçōes, e metade do produto arrecadado caberá aos titulares de direitos de autor, e a outra metade aos de direitos conexos, obedecidas, quanto a estes, as proporções estabelecidas nos parágrafos 20 e 3 do art. 6을 Lei no 4.944, de 06.04.1966.

Respeita, assim, os princípios orientadores da Lei no 5.988, que prestigia a ação das Associações arrecadadoras de direitos autorais, embora fiscalizando sua atuação e submetendo-a, através de um Escritório Central, à disciplina do Conselho Nacional de Direito Autoral.

Sob o aspecto da organização da administração, considera o TADDEO COLLOVA, Reproduction sonore et visuelle pour l'usage personnel, RIDA, vol. 99, 1979, págs. 77 - 155 e 100, págs. 3 - 125, Il Diritto di Autore, ํㅡ 2 - 3, 1979, págs. 265 - 306, Internationale Gesselschaft für Urheberrecht E.V., Viena, 1979, 317 págs., oportuno, diante da diversidade dos titulares com direito à remuneração, que seja realizada por uma entidade colateral, com autonomia tanto administrativa quanto de representação de órgãos de gerência.

Mas reconhece que essas condições podem ser preenchidas pela constituição de um serviço autônomo junto a uma sociedade de autores, principalmente caso esta já possua uma autonomia de administração e de representatividade no domínio da administração dos direitos de reprodução, como é justamente o caso do ECAD, no Brasil.

Pelo art. 5o Ministério da Fazenda é autorizado a fírmar convênio com o Escritório referido no art. $3^{\circ}$ desta Lei, para a cobrança da remuneração por ela instituída.

O dispositivo, - acentua ainda a "Justificação", tendo por meta viabilizar a cobrança da remuneração, com eficácia e economia, entrosa-se com o art. $2^{\circ}$ proposto, que visa definir o momento em que a remuneração se torna exigível.

E conclui ter sido para se evitarem transtornos à circulação dos suportes, que foi proposto que a cobrança da remuneração seja feita de uma só vez, para todos os titulares, e através de associação que os represente. A negociação com cada titular é evidentemente inviável. Para se evitarem abusos dos titulares de direitos autorais, a remuneração terá, quanto a seus critérios e valor, a indispensável chancela do Conselho Nacional de Direito Autoral.

Finalmente, pareceu de importância figurar um dispositivo que reafirme que nenhuma disposição do projeto diminui ou sequer altera a proteção já assegurada aos titulares de direitos autorais, para que ninguém ocorra que o pagamento de uma taxa autoriza o comércio de reproduções não consentidas. A re- 
muneração é instituída, exclusiva e restritamente como compensação à limitação contida no inciso II do art. 49 da Lei no 5.988, de 1973.

Como assinala TADDEO COLLOVA, as taxas fixas, trata-se de remuneração estabelecida sobre os aparelhos e seus suportes ou somente sobre uns e outros, não deveriam ser em princípio inferiores às previstas em geral na hipótese de reprodução das obras sobre exemplares pré-gravados destinados à venda ao público para uso privado, e no caso das concessões de licença geralmente praticadas a título de direitos conexos.

Entendemos que, a rigor, deveriam até ser maiores, se considerarmos que cada fita magnética ou similar, presta-se a ser usada diversas vezes.

\section{UMA COMPLEMENTAÇÃO NECESSÁRIA}

Mas o anteprojeto precisa ainda do aditamento de um dispositivo atinente à locação de discos, tapes, cassetes, cartuchos, filmes, etc., que, através de "clubes", está se multiplicando no Brasil, como no mundo inteiro, e cujos organizadores anseiam por regularizar a situação, à procura de um sistema que lhes permita retribuir os autores e demais titulares de direitos pelo aproveitamento de suas obras, para evitar sejam increpados de cometer um ilícito civil, e também um crime ao qual são impostas sanções severas.

As atividades dos videoclubes que alugam e reproduzem videocassetes - indaga HENRIQUE GANDELMAN - é legal? E que resposta devemos dar ao art. 38, quando afirma que a aquisição do original de uma obra, ou de exemplar de seu suporte material de utilização, não confere ao adquirente qualquer dos direitos patrimoniais do autor, ou titular?

Como os locatários desses tapes ou discos estariam isentos do pagamento complementar proposto para os adquirentes das fitas virgens, a única solução viável será cobrar dos organizadores uma percentagem sobre as receitas brutas, como se procede com relação aos ingressos aos cinemas, acréscimo esse que naturalmente irão cobrar dos próprios associados.

Com a aprovação do Anteprojeto oferecido, o Brasil será, depois da Áustria, a primeira Nação a instituir um sistema prático de cobrança, sem os inconvenientes que, nesse país, a legislação apresenta.

\section{UM "COMPROMISSO" NĀO PODE ESTABELECER OBRIGA- ÇŌES PARA EXCLUSIVAMENTE UMA DAS PARTES SIGNATÁ- RIAS}

QUESITO no 2. “'Objetiva o aludido 'Protocolo de Intençōes' a retirada 
dos videocassetes em uso há varios anos, à medida em que forem entrando os filmes 'etiquetados' pela Embrafilme. Mas a União Brasileira de Vídeo, contrariando a expectativa de repor os filmes não etiquetados à medida que fossem restirados, não cumpriu essa condição implícita. Pode uma das partes exigir o cumprimento, pela outra da avença que por sua vez não satisfaz?"

Assumiram os signatários a obrigação de não efetuarem novas cópias de nenhum dos itens relacionados no "Anexo n- 3", sem autorização expressa de seu titular e conseqüente direito ao porte da etiqueta de controle fornecida pela EMBRAFILME, nos termos da Resolução CONCINE no 97/83, nem utilizar cópias de título, mesmo não incluído nos acervos do aludido Anexo, salvo com expressa autorização de seu titular.

Os videoclubes e locadoras comprometeram-se a não receber de novos clientes filiados, sob nenhum pretexto, fitas de videocassetes sem a referida etiqueta de controle.

Um dos fundamentos do Protocolo consiste na consideração de que,

"após a entrada em vigor da Resolução no 97/83, do Conselho Nacional do Cinema - CONCINE, os legítimos produtores e distribuidores de videocassetes contendo obras intelectuais nacionais e estrangeiras estarão em condições de oferecer ao mercado cópias legais dessas obras, das quais são os únicos titulares"

$\mathrm{O}$ documento, na verdade, limita-se a firmar obrigações, algumas bem gravosas, para os videoclubes, distribuidores, locadores e revendedores de obras cinematográficas sob a forma de videocassetes, não assumindo os produtores cinematográficos e detentores de direitos sobre essas obras cinematográficas maior promessa do que uma vaga referência, que seria válida até o fim do ano, "a não acionar o CONCINE ou a EMBRAFILME, ou qualquer outro órgão na esfera judicial ou administrativa, para a apreensão das cópias dos títulos relacionados ao Anexo 3."

Não sendo os videoclubes, distribuidores, locadoras e revendedores "órgão" propriamente ditos, não fazendo parte de um ou de outro, nem sequer com essa ilusória prerrogativa seriam favorecidos.

Não é só.

Ao examinarem mais detidamente o Anexo no 3 do protocolo aludido, causou aos diretores dos videoclubes, bem como os locadores e revendedores de videocassetes, profunda estranheza a grande quantidade de títulos que o 
mesmo exibia. Embora não ignorando a existência dos componentes dessa relação, têm absoluta certeza de que muitos deles jamais chegaram ao Brasil, e têm sérias dúvidas de que os produtores de todos eles tenham investido os distribuidores locais da competente representação.

Acresce outra circunstância: diante da peculiaridade da lei de copyright norte-americana, muitos desses filmes, segundo revistas especializadas dos Estados Unidos, já caíram em domínio público.

"Os direitos de autor de um filme cinematográfico" - elucida WILLIAM K. EVERSON, Public-Domain Video: Why?, no exemplar de fevereiro da mesma Vídeo Review, pág. 43 - podem caducar por um bom número de razões, deixando-os cair no domínio público."

Enumera, em primeiro lugar, a mais comum de todas: é que o filme ou programa foi produzido por uma companhia independente, que não teve existência superior ao prazo de renovação do "copyright" Embora tenha havido pela nova lei norte-americana uma pequena alteração dos 29 anos seguidos por outros 28 , da lei anterior, grande número dos filmes hoje disponíveis cai em domínio público nesse período de 57 anos.

Em segundo lugar, muitos estúdios de produção venderam importantes títulos a outros estúdios para refazimento. Em muitos desses casos, nem os estúdios originais, nem os que refazem viram a necessidade de proteger o material original.

Em terceiro, um filme pode cair no limbo legal porque alguns dos seus direitos foram retirados, mas não outros.

"Em quarto, existe um sürpreendente número de casos em que os departamentos legais simplesmente 'comeram barriga' e falharam em renovar os direitos de autor quando poderiam tê-lo feito, ficando às vezes confusos por tão elementares matérias como as de dois filmes tendo o mesmo título."

Depois de uma série de considerações conclui que devido ao número crescente de possuidores de videocassetes e o relativamente baixo custo de produção, o mesmo título prolifera em uma quantidade de companhias diferentes, podendo, pois, ser emitido por duas ou até mais companhias.

Finalmente, voltando ao Protocolo, do Anexo no 5 resultam Empresas que não estão representadas no Brasil. Não poderiam, pois, mesmo que tivessem algum direito e quisessem reivindicá-lo.

Mas o fato mais relevante é que, longe de oferecer ao mercado cópias le- 
gais das obras a que se haviam comprometido, pelo menos implicitamente, para, por essa forma, permitir aos referidos videoclubes, distribuidores, locadores e revendedores de videocassetes continuarem com seu comércio, não ofereceram uma sequer que viesse substituir as que foram sendo paulatinamente retiradas.

Embora, ao o assinarem, percebessem que não era bom para eles o protocolo, acreditaram os videoclubes que sem ele seria pior. Mas só então perceberam o logro em que caíram: sua disposiçāo em cumprir o avençado, retirando filmes e cassetes que não correspondessem aos padrões firmados pela EMBRAFILME através de Resolução, não encontrou correspectividade alguma, nenhuma disposição apresentando os co-compromissários de suprir o mercado com novas produçōes para efetivar a substituição dos filmes e cassetes retirados.

Já quase sem títulos para fornecerem aos seus clientes, pois suas estantes estão praticamente vazias, vêm assim desmantelar-se toda a organização formada a duras penas bem como o trabalho até agora realizado, tornando-se vítimas de um verdadeiro e impiedoso "dumping", que as afixia e condena à morte. São centenas de entidades que mostraram sempre a melhor da disposições para se coadunarem com as exigências relativas ao direito de autor, embora até agora não tivessem meios legais ou práticos para atendê-la.

A correlação entre as prestações e contraprestaçōes dos signatários de qualquer compromisso dá-se o nome de "equilíbrio contratual"

LOUIS JOSSERAND, "Derecho Civil”, t. II, v. I, "Teoria General de las Obligaciones", trad., Bosch, Buenos Aires, 1952, numa síntese admirável, assinala a p. 262 que os autores têm apresentado sobre o caráter jurídico da resolução dos contratos por inexecução de obrigações, num grande número de explicações divergentes.

"Sem embargo" - acrescenta - "um ponto é certo: esta resolução se explica pela interdependência das obrigações nascidas de um mesmo contrato sinalagmático; seria contrário à lógica e à equidade que uma das partes fosse cumulada de direitos enquanto a outra sofresse falta dele.

Faça-se intervir a idéia da causa, como CAPITANT, ou a da equivalência, como MAURY, ou invoque-se a intenção provável das partes, cai-se sempre nesta conclusão essencial de que uma das partes não deve poder beneficiar-se da operação enquanto se sacrifica outra; desde o momento em que uma delas desrespeita a lei contratual, a outra deve, por sua vez, poder evadir-se."

"O direito de resolução", - adita - "apresenta duas idéias dominantes, dois standards fecundos em conseqüências: 
1- - Por um lado, reveste o caráter e assume a significação de uma verdadeira sanção dos compromissos contratuais;

$2^{\text {o }}$ - por outro, a resolução do contrato se produz em função da vontade presumida das partes; é interpretativa.

Sob o primeiro aspecto, a resolução constitui uma das sanções dos compromissos contratuais, é uma arma dada ao credor contra um devedor que não faz honra à sua assinatura.

Sob o segundo, ao mesmo tempo que sancionadora, a resolução é também interpretativa da vontade das partes.

É exatamente nesse sentido a lição de LUIGI MOSCO, em sua monografia específica, La Resolución de los Contratos por Incumplimiento, em tradução, acentuando, a p. 25 , que o fundamento da resolução consiste na reciprocidade entre as prestações, que devem conservar-se durante a execução. Não tem a obrigação de cumprir quem não pode obter da parte contrária a satisfação daquele interesse que o impeliu a contratar, e que está protegido por lei.

DIEGO ESPIN CANOVAS, Catedrático de Direito Civil da Universidade de Salamanca, consagra 18 páginas (274-292) do vol. 26-27 da "Revista del Instituto de Derecho Comparado", 1966, Barcelona, ao tema: "La sanción por la inejecución contractual", que inicia com as seguintes palavras:

"El cumprimiento de las obligaciones contractuales no puede quedar a merced de la vontad de las partes, que por virtud del contrato quedaron vinculadas; el Codigo civil expressa de modo terminante esta vinculatoriedad al disponer que "las obligaciones que nacen de los contratos tienen fuerza de ley entre las partes contratantes, y deben cumplirse al tenor de los mismos" "(art. 1091).

Aplaude a orientação do Tribunal Supremo, que exige que a vontade seja "deliberadamente rebelde" à execução voluntária, entendendo que semelhante interpretação jurisprudencial está de acordo com a trajetória histórica que concebeu a resolução como um recurso em favor do que cumpria, para liberá-lo do contrato, quando a outra parte não estava disposta a satisfazer, mas esta sanção - adita - requer uma situação de gravidade, de importância.

Separa por sua vez o Catedrático da Universidade de Direito de Minas Gerais, JOSÉ DO VALLE FERREIRA, Resolução dos Contratos, Revista dos Tribunais, vol. 403, 1969, p. 2-21, do art. 1092 e parágrafo do Código Civil,

"três normas muito claras e do maior alcance: a) exceção de 
não cumprimento; b) garantia de execução; finalmente, c) resolução do negócio. Em outras palavras: quando o contrato se qualifica na classe dos bilaterais, logo aparece a possibilidade de ser modificada a técnica jurídica da execução."

Acentua que o velho brocardo: "inadiplenti non est adimplendum" é uma exceção que compreende duas modalidades: "exceptio non adimpleti contractus", para o caso de inadimplemento total quando já se iniciou a execução mas o cumprimento foi mau, e consigna:

"A parte lesada pela impontualidade de outra tem a faculdade de optar entre a execução da obrigação e a dissolução do contrato..."

Disserta a respeito do adágio "frangenti fidem non est fides servanda", construção dos canonistas recebida por DOMAT e parcialmente por POTHIER, e critica a expressão imprópria empregada pelo parágrafo único do art. 1092, falando em rescisão, quando, com certeza, tratava de resolução do contrato.

Passa em resenha, a p. 16, os diversos processos técnicos, imaginados no propósito de resguardar a boa-fé e garantir uma situação de igualdade, para que um dos contraentes não tire vantagens sem executar o que prometeu em troca, e chega ao ponto que interessa:

"A relação mútua de dependência é a idéia fundamental que necessariamente vai orientar o intérprete, pois na estrutura dos contratos bilaterais nãn devemos ver apenas obrigaçōes que se acompanham.

Antes, elas se apresentam condicionadas, numa situação de correlatividade, bastante para incluir o sentido econômico da equivalência. Esta correlação é irrecusável no momento de se formar a convenção.

Não basta, é evidente, a existência originária de semelhante nexo entre as duas obrigações; se o direito protege a relação que se forma, deve manter a mesma posição até que tudo se liquide. Isto quer dizer que a interdependência genética implica necessariamente numa interdependência funcional, como costumam dizer os italianos e foi bem fixado na lição de MOSCO (La Rizoluzione del Contratto per Inadempimento, pág, 12 e segs.). Vem daí o interesse em defender aquela conexão entre prestação e contraprestação, isto é: o "sinallagma dell'onerosita", no dizer de MARIO SIMONE (Rivista Trimestrale di Diritto e Procedura Civile, vol. II, pág. 48, no 10 ). Desse modo e só assim, a atribuição é correlativa. Então, pode-se concluir, a obediência aos requisitos necessários à formação do contrato terá assegurado uma posição inicial de equilíbrio; na fase executiva, é lógico que deve permanecer a mesma simetria, com a facul- 
dade de resolução, reservada a uma das partes contra a impontualidade da outra."

Ora, é claro que o objetivo de qualquer compromisso é o seu exato cumprimento. Nenhum contratante bem intencionado contrataria se pudesse prever que as cláusulas avançadas não seriam exatamente cumpridas, ou se imaginasse a possibilidade de ocorrências que viessem retirar ao mesmo a sua finalidade.

Nestas condições, não tendo a União Brasileira de Vídeo efetuado a reposição dos filmes não etiquetados que foram retirados da circulação, compromisso básico do Protocolo de Intenções a que alude o quesito, não tem a menor condição de exigir o cumprimento da retirada dos restantes videocassetes em uso há muitos anos, tanto mais que nem sequer comprovou a titularidade e a representação de grande número deles.

Pior do que isso: semelhante comportamento implica na resolução, ou melhor, na quebra do contrato, dando ampla liberdade aos videoclubes, distribuidores, locadores e revendedores de obras cinematográficas protegidas, em forma de videocassetes, de se colocarem na posição em que se encontravam antes de aporem sua assinatura no mesmo. Nas palavras de FRANCESCO MESSINO, Dottrina Generale del Contratto, Milão, Giuffré, 1952, p. 471:

"As circunstâncias, os fatos e os comportamentos que dão lugar à resolução são tomados em consideração pela lei, porque alteram as relações entre os contraentes, como é óbvio, inicialmente constituídas, ou perturbam o normal desenvolvimento (execução) do contrato, de modo que este não pode continuar vinculando as partes na forma originária porquanto veio a modificar-se ou - mesmo - veio a faltar aquela composição de interesses de que o mencionado contrato constituía a expressão.

Justamente por isso a resolução põe fim ao contrato. Mas ela importa implicitamente em pôr fim também à relação obrigatória gerada pelo contrato. Somente que a resolução costuma ser referida logicamente ao contrato, ou porque o contrato ainda não foi executado ou porque ele é de execução continuada."

Nem caberia ser diferente, pois, se o Código todo se desvela em elaborar regras cuidadosas e minuciosas no que diz respeito à formação e às formalidades inerentes ao ajuste, não poderia, depois de firmado, abandoná-lo ao arbítrio completo de um dos contratantes.

É o que ilustra excelentemente LUIGI MOSCO: nos contratos onerosos os laços de interdependência ou causalidade se manifestam não-somente na fase formativa, como na funcional. 
A tutela da interdependência das respectivas obrigações seria insuficiente se se limitasse a salvaguardar a plena reciprocidade inicial, uma vez que pode muito bem ocorrer que um contrato oneroso, estipulado em condições de livre autodeterminação por ambas as partes, não possa cumprir-se.

Demonstra que seria ilusória a proteção jurídica se se limitasse ao momento formativo, uma vez que não garantiria ou outro contratante a verdadeira realização ao dever recíproco.

Consiste o fundamento da relação - prossegue - na relação de reciprocidade entre as prestações, que deve conservar-se durante a execução. Não teria obrigação de cumprir quem não pode obter da parte contrária a satisfação daquela vantagem que a levou a contratar, e que está tutelada pela lei.

Assim como se concede ao credor uma ação para a execução coativa na satisfaçāo do seu interesse, também, com a mesma finalidade, se lhe atribui uma ação que tende a liberá-lo do vínculo que decorre da obrigação correlativa.

A interdependência entre as prestaçōes faz com que o proveito do credor não se limite à prestação que lhe é devida, mas se estenda também à dispensa do débito que grava sobre ele em todos os casos em que a prestação contrária, embora podendo realizar-se, não lhe ofereça qualquer utilidade. Do contrário, o interesse do credor se veria frustrado, conseguindo apenas uma prestação inútil, em correspondência à utilidade que prestou.

VALLE FERREIRA também acentua que ao disciplinar, em regime especial, com regras específicas, os negócios bilaterais, deixou claro o Código Civil que o vínculo de correlação entre as obrigações, manifestado na fase formativa, deve prolongar-se até o instante da execução, pois o contrato bilateral, por definição e por natureza, sugere idéia de uma relação mútua entre as duas obrigações principais.

"Nesta conformidade, dependendo as obrigações umas das outras, quer quanto à existência, quer quanto à execução, é evidente que uma correspondência entre as duas obrigaçōes deve levar a uma correlação necessária entre as duas prestações, circunstâncias que não passou despercebida ao velho PLANIOL (Traité Élémentaire, vol. II, nº 1309), nem à fina observação de MESSINEO (Dottrina Generale del Contratto, Cap. VIII, no 2)."

Assinala que feito que seja o contrato, já na qualidade de lei entre as partes, só pode ser modificado ou revogado se ocorrer novo consentimento, e lembra que quando as obrigações sāo recíprocas e conexas, a lei altera os princípios de direito comum, para admitir um processo singular e subsidiário, em benefício do credor prejudicado. 
A resposta ao quesito só podia ser, portanto, terminantemente negativa.

\section{A DISTRIBUIÇÃo E LOCAÇĀo dE VIDEOCASSETES NĀO SÃo "CRIMES" CONTRA A PROPRIEDADE IMATERIAL}

QUESITO no 3. "Caso venha a UBV tomar providências de natureza civil ou mesmo penal contra os videoclubes, os distribuidores, locadores e revendedores de obras cinematográficas sob a forma de videocassetes, que providências legais poderiam estes tomar?"

Para bem situarmos o problema, vejamos antes de mais nada como se enquadram atualmente, do ponto de vista legal, os locadores ou clubes de videocassetes, já existentes em considerável número no mundo inteiro.

- No Brasil, apenas a consulente reúne 240 associados, englobando 153 mil fitas. Seu potencial humano é revelado pelo cálculo de cada loja contar com uma média de três empregados, fato bem expressivo para demonstrar que o problema não é exclusivamente jurídico, mas também social, aspecto que não pode ser menosprezado, uma vez que essas entidades desenvolvem uma atividade que não é ilícita por sua natureza.

Aplicada com rigor a Resolução no 97, de CONCINE - observa ADELINO DOS SANTOS ABREU, A regulamentação da videocomunicação, Guia do Vídeo no Brasil, S. Paulo, Olhar Eletrônico Produçōes Ltda., sem data indicada mas lançado em setembro de 1984 - terminaria com mais de 10 mil empregos diretos, 60 mil clientes, responsáveis por uma retirada de 800 mil fitas por mês.

No âmbito civil, a aquisição do original de uma obra ou de exemplar, instrumento, veículo ou material de utilização - dispōe o art. 38 da Lei no 5.988, de 14.12.1973, não confere ao adquirente qualquer dos direitos patrimoniais do autor, ou titular.

A violação do dispositivo dará margem a medidas de busca e apreensão e a pedidos de indenização por perdas e danos, devido ao uso público não autorizado.

São os contornos criminais os que mais preocupam, à vista do disposto no art. 184 do Código Penal.

Sua redação foi alterada pela Lei no 6.895 , de 17.12.1980, mantendo a detenção de três meses a um ano, mas elevando a alternativa da multa, que era de hum cruzado a cinco cruzados novos, para dois cruzados a dez cruzados novos. 
A inovação mais relevante decorre todavia do acréscimo dos:

"§ 1 Se a violação consistir na reprodução, por qualquer meio, de obra intelectual, no todo ou em parte, para fins de comércio, sem autorização expressa do autor ou de quem o represente, ou consistir na reprodução de fonograma e de videofonograma, sem autorização do produtor ou de quem o represente:

$\mathrm{NCz} \$ 50,00$.

Pena - reclusão de um a quatro anos e multa de $\mathrm{NCz} \$ 10,00$ a

$\S 2$ - Na mesma pena do parágrafo anterior incorre quem vende, expõe à venda, introduz no País, adquire, oculta ou tem em depósito, para o fim de venda, original ou cópia de obra intelectual, fonograma ou videofonograma, produzidos com violação de direito autoral."

No caso dos clubes de videocassetes, quem incorrerá especificamente nesses dispositivos?

Divergimos de J. PEREIRA, Videocassetes e Direitos Autorais, o Estado de S. Paulo de 28.02.1982 que sustenta serem os diretores, associados e demais envolvidos, por entendermos que a matéria não pode ser considerada assim globalmente, sendo necessário estabelecer algumas distinções.

Assim, em primeiro lugar, enquanto se limitarem tais diretores a receber, seja de quem for, os videocassetes licitamente gravados, pagando, como se propõem, os direitos acaso devidos a quem provar que é deles titular, não incorrerão nos dispositivos, pois não estarão "reproduzindo por qualquer meio, no todo ou em parte, para fins de comércio, etc."

Também não poderão ser por eles alcançados desde que não os estejam vendendo ou expondo à venda, etc., por não se poder aplicar à locação, que é a hipótese que estamos considerando, dispositivo de ordem penal relativo à reprodução para fins de comércio, indicando claramente venda, inaplicável como é a analogia aos dispositivos de natureza criminal.

Muito menos nelas incorrerão as associaçōes, quando não visem "fim de comércio".

Ainda que nessas expressões se pretendesse vislumbrar a possibilidade de inculcar a locação, sempre permaneceria no espírito do julgador uma dúvida que fatalmente o levaria à absolvição, por não corresponder a hipótese ao figurino traçado pela lei penal, em obediência ao brocardo in dubio pro reo. 
Apenas na eventualidade dos diretores, e, aí sim, dos associados, recebendo os videocassetes em locação, se porém a reproduzí-los, e, ainda assim, não para uso seu particular, ou dentro do âmbito da sua família, mas, como exige a redação do aludido $\S 1 \%$, para fins de comércio, sem autorização do titular do direito, é que lhes será aplicável o dispositivo.

Nestas condições, reconhece o art. 26 da Lei no 5.988, caber exclusivamente ao diretor o exercício dos direitos morais sobre a obra cinematográfica, mas ele só poderá impedir a utilização da película após obter sentença judicial passada em julgado.

O "Protocolo de Intençōes", - percebe-se claramenre - já obtém, independentemente de qualquer processo ou julgamento, a antecipação de uma sentença condenatória que absolutamente não pode abranger, como já ficou demonstrado, todas as hipóteses de aproveitamento de obras cinematográficas.

$\mathrm{Na}$ própria reunião promovida pela União Brasileira de Vídeo aos 29.07.1983, ficou evidenciado que, como reconheceu o próprio Dr. Henrique Gandelman, patrono da mesma, sendo ela composta de membros nacionais e estrangeiros, "apenas subsistirá como uma entidade informal, desde que, de acordo com os arts. 103 e 104 da Lei no 5.988, os titulares de "copyright" estrangeiros não podem ser membros efetivos de associações para a defesa judicial ou extrajudicial de seus direitos autorais, nem para cobrança dos mesmos.

Além disto, existem muitas restrições severas referentes a estas associações, inclusive sua aprovação prévia pelo Conselho Nacional de Direito Autoral, a fim de tornar legal a sua constituição como entidade de titulares de "copyright."

Ora, pessoa jurídica de existência "apenas informal" não passa de uma sociedade de fato, sem poder de agir contra terceiros.

Como o art. 30 da Lei no 5.988 coloca na dependência de permissão do autor toda forma de utilização de sua obra, inclusive sua comunicação ao público, direta ou indireta, por qualquer forma ou processo, entre as quais a videofonografia, prevendo o parágrafo único, que ainda quando essa fixação for autorizada, sua execução pública, por qualquer meio, só se poderá fazer com a permissão prévia, para cada vez, do titular dos direitos patrimoniais do autor é bem de ver que, sem embargo das modificaçōes introduzidas no mencionado dispositivo legal, não serão os locatários, mas os diretores e administrados desses clubes que estarão violando esses dispositivos, pois a eles é que cabe a iniciativa de solicitar e obter a permissão.

Qual seria a solução do problema? 
Considera o relatório da IFPIVIDEO que um direito de distribuição poderia vir a fortalecer o controle da locação dos videogramas, ainda que seus efeitos estejam atualmente limitados (com exceção dos países nórdicos). Nestes, o direito de distribuição subsiste mesmo depois que o videograma tenha sido vendido ou alugado, tendo portanto o produtor o direito de controlar não-somente a locação e o empréstimo das cópias após sua venda, mas também sua venda ulterior.

Um direito privado específico relativo à locação poderia fundar-se sobre este precedente, e dariạ o direito de impedir ou de obter retribuiçōes sobre a locação ou o empréstimo dos videogramas depois que tenham sido vendidos sem procurar todavia controlar as vendas ulteriores.

É difícil no momento - prossegue - prever se, a comercialização dos videogramas se fará, no futuro, através da locação ou da venda.

A locação de videocassetes já representa um volume de negócios considerável. Com decorrência da incompatibilidade presente dos sistemas, e ainda, do progresso constante das técnicas, o equipamento e os suportes materiais em sua forma atual riscam muito de caírem em desuso a breve prazo, estado de coisas portanto que leva o público antes alugar do que a comprar.

O sistema de locações de videogramas destinado ao uso privado desenvolveu-se a tal ponto que, a despeito dos problemas que ele apresenta, é necessário considerá-lo como um meio suplementar e natural de aproveitamento dos suportes audiovisuais para uso privado.

Aponta, todavia, as razōes pelas quais durante alguns anos este sistema poderia bem constituir o método principal de aproveitamento:

a. Em um grande número de casos, os suportes audiovisuais para uso privado são produtos que o consumidor não deseja ver senão uma só vez, ou que não suportam a repetição freqüente, contrariamente ao que ocorre com os produtos sonoros.

b. Os suportes audiovisuais para uso privado permanecem bastante custosos. Embora esteja prevista uma baixa, se um consumidor tem a possibilidade de alugar um cassete ou um vídeo por preço bem inferior, é provável que se interesse muito mais pelo vídeo, e, de maneira particular, pelos programas que desejaria ver uma vez, mas pelos quais ele não pode ou não quer gastar a alta quantia necessária para a compra de uma cópia.

c. O produto (cassetes e discos vídeo) é em geral apto a resistir à manipulação pelo público que o aluga (embora pesquisas sejam necessárias para po- 
der indicar o número de vezes que um cassete pode ser utilizado; as estimativas variam atualmente entre 20 e 2.000 vezes).

No que diz respeito à utilização dos direitos de autores e conexos devidos pelos exibidores cinematográficos pela execução pública de obras musicais e lítero-musicais, de fonogramas, interpretações e execuções incluídas nas película, a autorização cabe ao Escritório Central de Arrecadação e Distribuição $\mathrm{ECAD}$, que poderá realizar o recebimento diretamente ou mediante convênio com a entidade interessada, e que arrecadará dos exibidores cinematográficos os direitos autorais devidos desde 01.01.1982, nos termos do despacho do Colegiado na 93a Reunião Ordinária, de 10.02.1982.

Embora a decisão inclua os direitos não musicais, deliberação ulterior os exclue do âmbito do ECAD.

A Tabela única elaborada pelo ECAD foi homologada pelo CNDA pela Resolução no 25, de 11.03.1981, publicada no DOU de 19.10.1981 (Código 30).

Com isso teremos no entanto encontrado solução apenas parcial para o problema, pois escapam à competência do ECAD parcelas que cabem ao autor do roteiro original, ou adaptado, ao eventual adaptador, ao realizador do filme, aos artistas, etc.

O melhor critério, no que diz respeito aos cinemas, continua sendo o de uma percentagem sobre o valor de ingresso.

Como, na hipótese em estudo, não se cogita de entrada, será o de uma percentagem sobre o valor pago mensalmente pelos sócios ou assinantes de videoclubes ou retribuição dos locadores, na proporção fixada na Tabela Única, e se não for prevista, na mesma proporção do que for cobrado em favor dos artistas intérpretes e executantes.

Não tendo o ECAD competência para efetuar esse último recebimento, cabe uma consulta à Associação Brasileira de Produtores Cinematográficos, que alterou seus Estatutos por decisão em Assembléia Geral de 01.10.1981, para incluir entre seus objetivos, art. 2:

"g. administrar e distribuir os direitos autorais e conexos de que sejam titulares os seus associados e representantes (sic) decorrentes da exibição pública de filmes cinematográficos, da sua radiodifusão e da sua reprodução em videocassetes, videodiscos e outros sistemas de divulgação existentes ou que virem a ser criados, observadas as disposições legais e regulamentares referentes à arrecadação e distribuição, criadas pelo Conselho Nacional de Direito Autoral. 
h. representar os seus associados, na defesa e cobrança dos seus direitos autorais e conexos, patrin.oniais e morais, para isso praticando os atos que se fizerem necessários, judicial e extrajudicialmente."

Se não for alcançado um entendimento nessa base, para evitar surpresas desagradáveis, deverão os videoclubes, os distribuidores, locadores e vendedores de obras cinematográficas depositar em Juízo, até que a matéria seja definida por meio de lei ou por decisão judicial, a importância correspondente à parcela cobrada a título de direitos autorais nos filmes cinematográficos, calculada não evidentemente sobre o preço de entrada, que, no caso, não existe, mas sobre a mensalidade ou calculando-se a proporcionalidade, sendo outra a forma de remuneração.

É claro que, com isso, terão os videoclubes, distribuidores, locadores e revendedores de obras cinematográficas sob a forma de videocassete resolvido o seu problema. $\mathrm{O}$ mesmo não ocorrerá com as empresas cinematográficas, que enfrentarão a esfinge de quem, a que título, em que proporção e com que provas irá levantar as quantias depositadas.

Quanto ao mais, outras providências não poderão tomar aqueles senão apresentar, tanto no âmbito penal, quanto no civil, suas defesas e contestaçōes, mostrando a inviabilidade do "Protocolo de (más) Intenções" e a impossibilidade em que se encontram de cumprir um diploma legal "in fieri", ainda inexistente, mesmo na maioria dos países mais adiantados nesta matéria.

São Paulo, 9 de outubro de 1986. 